\title{
Kajian Yuridis Pelaksanaan Roya Obyek Hak Tanggungan Atas Tanah Oleh Badan Pertahanan Kota Mataram
}

\author{
Wiwiek Wahyuningsih ${ }^{1}$ \\ Fakultas Hukum Universitas Mataram, \\ Jln. Majapahit No. 62 Mataram 83125, \\ Telp. (0370), 633035, Fax. 626954 \\ Email: wiwikwahyuningsih@mail.com \\ Arba $^{2}$ \\ Fakultas Hukum Universitas Mataram, \\ Jln. Majapahit No. 62 Mataram 83125, \\ Telp. (0370), 633035, Fax. 626954 \\ Email:wiwikwahyuningsih@mail.com \\ Shinta Andriyani ${ }^{3}$ \\ Fakultas Hukum Universitas Mataram, \\ Jln. Majapahit No. 62 Mataram 83125, \\ Telp. (0370), 633035, Fax. 626954 \\ Email:wiwikwahyuningsih@mail.com
}

\section{ABSTRAK}

Hak Tanggungan adalah hak untuk menjaminkan hak atas tanah sebagai jaminan kredit pada Bank. Hak Tanggungan adalah merupakan perjanjian accecoire (ikutan) dari perjanjian utama, yaitu perjanjian utang piutang. Hak Tanggungan wajib dibuatkan Akta Pemberian Hak Tanggungan dan wajib didaftarkan di Kantor Pendaftaran Tanah Badan Pertanahan Nasional untuk memperoleh sertifikat untuk jaminan kepastian hukum, dan wajib pula diroya' jika hutang piutang berakhir. Roya adalah pencoretan terhadap beban jaminan suatu hak atas tanah yang dijadikan obyek Hak Tanggungan yang telah berakhir atau telah dihapus karena sudah berakhir kreditnya oleh Kantor Pendaftaran Tanah atas permintaan pihak yang berkepentingan.

Penelitian ini adalah penelitian hukum empiris yang bertujuan untuk mengkaji secara yuridisempiris pelaksanaan roya obyek Hak Tanggungan oleh Kantor Pendaftaran Tanah Kota Mataram.

3 Dosen Fakultas Hukum Universitas Mataram. 
Hasil penelitian menunjukan bahwa pelaksanaan pendaftaran roya Hak Tanggungan Atas Tanah telah diatur dengan jelas persyaratan dan tatacaranya. Sedangkan pelaksanaan roya obyek Hak Tanggungan di Kantor BPN Kota Mataran telah terlaksana dengan baik sesuai dengan ketentuan dan prosedur yang telah ditentukan oleh peraturan perundang-undangan yang berlaku.

Kata Kunci : Roya Hak Tanggungan.

\section{ABSTRACT}

Deposit Rights is the right to pledge the right to land as a credit guarantee to the Bank. The Deposit Rights is an accecoire agreement (agreement) of the main agreement, namely debt agreement receivable. The right of Dependent must be made a Deed of Granting of Dependent Rights and must be registered in the Land Registry Office of the National Land Agency to obtain a certificate for guarantee of legal certainty, and must also diroya if the debts are due. Roya is a deletion of the security expense of a land right that is the object of the Mortgage Right that has expired or has been removed because it has already ended its credit by the Land Registry Office at the request of the interested parties.

This research is empirical law research that aims to examine the juridical-empirical implementation of roya Object of Mortgage by the Land Registry Office of Mataram City. The result of the research shows that the implementation of registration of the Land Rights of the Land on Land has been clearly regulated with the requirements and procedures. While the implementation of Roya Object of Mortgage Rights at the Office of BPN Kota Mataran has been implemented well in accordance with the provisions and procedures that have been determined by the applicable legislation.

\section{A. PENDAHULUAN}

Hak Tanggungan Atas Tanah adalah hak jaminan yang diberikan oleh pemegang hak atas tanah selaku debitur atau penjamin debitur kepada penerima Hak Tanggungan selaku kreditur untuk menjaminkan hutangnya berdasarkan perjanjian hutang piutang. Dalam perjanjian kredit antara lembaga perbankan sebagai kreditur dengan nasabah sebagai debitur, maka dimungkingkan adanya perjanjian tambahan berupa perjanjian hak tanggungan. Hak Tanggungan merupakan perjanjian accesoire (ikutan) dari perjanjian utama, yaitu perjanjian utang piutang (kredit).

Setiap perjanjian memberikan jaminan kredit dengan hak tanggungan wajib dibuatkan Akta Pemberian Hak Tanggungan (APHT) sebagaimana yang diatur di dalam Pasal 10 ayat (2) Undang-Undang Nomor 4 Tahun 1996 tentang Hak Tanggungan Atas Tanah Beserta Benda-benda Yang Berkaitan Dengan Tanah. Pembuatan APHT dilakukan oleh, dan dihadapan Pejabat Pembuat Akta Tanah. Setalah dibuatkan APHT maka kewajiban selanjutnya adalah melakukan Pendaftaran pada Kantor Pertanahan sebagaimana diatur di dalam Pasal 13 ayat (1). Pendaftaran APHT ini harus dilakukan selambatlambatnya 7 (tujuh) hari kerja setelah penandatanganan APHT, dan selanjutnya APHT tersebut dan warkahnya wajib dikirimkan bersama warkah lain yang diperlukan kepada Kantor Pertanahan (Pasal 13 ayat 2).

Pendaftaran APHT dimaksud guna memperoleh sertifikat sebagai jaminan kepastian hukum dan hak dari pelaksanaan hak tanggungan tersebut, sebab sertifikat pendaftaran APHT itulah yang menentukan bahwa perbuatan hukum tersebut mempunyai kekuatan hukum yang sempurna seperti Keputusan Pengadilan. Sebab sertifikat 
tersebut memuat irah-irah "Demi Keadilan Berdasarkan Ketuhanan Yang Maha Esa" (Pasal 14 ayat 2) UUHT.

Apabila Hak Tanggungan itu berakhir atau hapus, maka Kantor Pendaftaran Tanah melakukan pencoretan catatan Hak Tanggungan yang terdapat di dalam Buku Tanah dan sertifikatnya (Pasal 22 ayat 1) UUHT. Selanjutnya dengan hapusnya Hak Tanggungan, sertifikat Hak Tanggungan yang bersangkutan ditarik dan bersamasama buku tanah Hak Tanggungan dinyatakan tidak berlaku lagi oleh Badan Pertanahan (Pasal 22 ayat 2). Pencoretan Hak Tanggungan tersebut diajukan oleh pihak yang berkepentingan kepada Kantor pendaftaran Tanah setelah dinyatakan oleh kreditur bahwa hubungan utang piutang antara kreditur dan debitur telah berakhir (Pasal 22 ayat 3). Pelaksanaan pencoretan Hak Tanggungan dilakukan oleh Badan Pertanahan dalam waktu 7 (tujuh) hari kerja setelah diterimanya permohonan untuk melaksanakan pencoretan Hak Tanggungan.

\section{B. METODE PENELITIAN}

\section{Jenis Penelitian}

Penelitian ini adalah penelitian hukum empiris adalah penelitian hukum yang mengamati dan mengkaji penerapan norma-norma hukum di lapangan dengan berbasis pada ilmu hukum normative, yaitu peraturan perundang-undangan, asas-asas hukum, konsep-konsep hukum, kemudian melakukan pengamatan tentang bagaimana reaksi dan interaksi yang terjadi ketika sistem norma itu bekerja di dalam masyarakat. ${ }^{1}$

\section{Metode Pendekatan}

Penelitian ini adalah penelitian hukum empiris, maka pendekatan yang dipergunakan adalah pendekatan

${ }^{1}$ Mukti Fajar ND dan Yulianto Achmad, Dualisme Penelitian Hukum, Normatif \& Emperis, Yogyakarta, Pustaka Pelajar, 2010, hlm. 47. normatif-empiris. Pendekatan normatif yang dipergunakan untuk mengkaji norma-norma, konsep-konsep dan asasasas hukum dan pendapat-pendapat ahli hukum yang berkatan dengan obyek penelitian ini, sedangkan pendekatan empiris dipergunakan untuk melakukan pengumpulan data lapangan. Dengan demikian pendekatan yang akan digunakan adalah pendekatan perundang-undangan (statute approach), pendekatan konsep (conceptual approach). Sedangkan pendekatan empirik menggunakan pendekatan sosiologis (sociologis approach). Pendekatan empirik itu dipergunakan untuk memperoleh datadata dan informasi yang bersifat empirik di lapangan.

\section{Sumber bahan hukum dan data}

Bahan hukum diperoleh melalui kajian kepustakaan (liberary reseach), sedangkan data diperoleh melalui penelitian lapangan (fild research). Bahan Kepustakaan terdiri dari bahan hukum primer berupa peraturan perundang-undangan, bahan hukum sekunder berupa konsep-konsep teori dan pendapat para ahli, buku-buku, dan hasil-hasil penelitian, dan bahan hukum tertier berupa kamus-kamus bahasa dan kamus hukum. ${ }^{2}$ Sedangkan data lapangan berupa data primer yang diperoleh melalui mewawancara dengan responden dan informan, dan data sekunder bersumber dari dokumen resmi di Kantor Badan Pertanahan Mataram.

\section{Teknik Pengumpulan Bahan Hukum dan Data}

Pengumpulan bahan kepustakaan dilakukan dengan mengkaji dan menganalisis bahan-bahan kepustakaan, sedangkan pengumpulan data lapangan dilakukan dengan mewawancarai respoden, yaitu pemberi Hak

\footnotetext{
2. Soerjono Soekanto, Pengantar Penelitian Hukum, Universitas Indonesia, Pres. Jakarta. 1984, Hal. 12
} 
Tanggungan dan pemegang Hak Tanggungan, serta Kepala Kantor Pendaftaran Tanah, untuk menginventarisir dan mengidentifikasi data pelaksanaan pencoretan (roya) atas Hak Tanggungan yang telah berakhir atau hapus.

\section{Teknik Analisis Bahan Hukum dan} Data

Untuk mengkaji hukum dari aspek normatif (law in book), maka metode normatif analitis, yaitu melalui penafsiran hukum baik penafsiran otentik, penafsiran gramatikal, dan penafsiran historical, sedangkan analisis data dilakukan secara kualitatif dan kuantitatif, selanjutnya disimpulkan secara deduktif.

\section{PEMBAHASAN}

A. Pengaturan Hukum Tentang Proses Pelaksanaan Roya (Pencoretan) Hak Tanggungan Atas Tanah Setelah Berakhirnya Perjanjian Kredit

Pencoretan Hak Tanggungan yang telah berakhir adalah suatu keharusan. Adapun pengaturan hukum mengenai pelaksanaan pencoretan (roya) Hak Tanggungan yang telah berakhir jangka waktunya adalah sebagai berikut:

1. Undang-Undang Nomor 5 Tahun 1960 (UUPA), Pasal 19 ayat (1) menentukan: Untuk menjamin kepastian hukum oleh Pemerintah diadakan pendaftaran tanah diseluruh wilayah Republik Indonesia menurut ketentuan-ketentuan yang diatur dengan Peraturan Pemerintah. Atas dasar ketentuan ini pemerintah membentuk Peraturan Pemerintah tentang Pendaftaran Tanah.

2. Undang-Undang Nomor 4 Tahun 1996 tentang Hak Tanggungan Atas Tanah Beserta Benda-benda Yang Berkaitan dengan Tanah.
Adapun ketentuan tentang pendaftaran Hak Tanggungan sebagai berikut:

Pasal 13 menentukan:

(1) Pemberian Hak Tanggungan wajib didaftarkan pada Kantor Pertanahan.

(2) Selambat-lambatnya 7 (tujuh) hari kerja setelah penandatanganan Akta Pemberian Hak Tanggungan sebagaimana dimaksud dalam Pasal 10 ayat (2), PPAT wajib mengirimkan Akta Pemberian Hak Tanggungan yang bersangkutan dan warkah lain yang diperlukan kepada Kantor Pertanahan.

(3) Pendaftaran Hak Tanggungan sebagaimana dimaksud pada ayat (1) dilakukan oleh Kantor Pertanahan dengan membuatkan buku tanah Hak Tanggungan dan menca-tatnya dalam buku tanah hak atas tanah yang menjadi obyek Hak Tanggungan serta menyalin catatan tersebut pada sertipikat hak atas tanah yang bersangkutan.

(4) Tanggal buku tanah Hak Tanggungan sebagaimana dimaksud pada ayat (3) adalah tanggal hari ketujuh setelah penerimaan secara lengkap surat-surat yang diperlukan bagi pendaftarannya dan jika hari ketujuh itu jatuh pada hari libur, buku tanah yang bersangkutan diberi bertanggal hari kerja berikutnya.

(5) Hak Tanggungan lahir pada hari tanggal buku tanah Hak Tanggungan sebagaimana dimaksud pada ayat (4).

Pasal 14 menentukan:

(1) Sebagai tanda bukti adanya Hak Tanggungan, Kantor Pertanahan menerbitkan sertipikat Hak Tanggungan sesuai dengan peraturan perundang-undangan yang berlaku.

(2) Sertipikat Hak Tanggungan sebagaimana dimaksud pada ayat (1) memuat irah-irah dengan kata-kata "DEMI

KEADILAN 
BERDASARKAN KETUHANAN YANG MAHA ESA".

(3) Sertipikat Hak Tanggunan sebagaimana dimaksud pada ayat (2) mempunyai kekuatan eksekutorial yang sama dengan putusan pengadilan yang telah memperoleh kekeuatan hukum tetap dan berlaku sebagai pengganti grosse acte Hypotheek sepanjang mengenai hak atas tanah.

(4) Kecuali apabila diperjanjikan lain, sertipikat hak atas tanah yang telah dibubuhi catatan pembebanan Hak Tanggungan sebagaimana dimaksud dalam Pasal 13 ayat (3) dikembalikan kepada pemegang hak atas tanah yang bersangkutan.

(5) Sertipikat Hak Tanggungan diserahkan kepada pemegang Hak Tanggungan.

Perintah pendaftaran Hak Tanggungan Atas Tanah dimaksudkan untuk agar memberikan jaminan kepastian hukum dan hak bagi para pihak dalam melakukan perbuatan hukum tersebut. Terutama bagi pihak kreditur, dengan pendaftaran Hak Tanggungan atas Tanah yang menghasilkan sertifikat Hak Tanggungan akan memberikan kemudahan dan kepastian hukum bagi pihak kreditur untuk melakukan eksekusi jika terjadi wanprestasi dari debitur, karena sertifikat tersebut memuat title eksekuturial dengan dicantumkannya ira-ira: Demi Kradilan Berdasarkan Ketuhanan Yang Maha Esa”, sehingga mempunyai kekuatan eksekutorial yang sama kedudukannya dengan Putusan Pengadilan.

Sedangkan pengaturan secara khusus tentang pencoretan dan pendaftaran pencoretan Hak Tanggungan diatur di dalam Pasal 22 dan Pasal 54. Pasal 22 menentukan sebagai berikut:

(1) Setelah Hak Tanggungan hapus sebagaimana dimaksud dalam Pasal 18, Kantor Pertanahan mencoret catatan Hak Tanggungan tersebut pada buku tanah hak atas tanah dan sertipikatnya.
(2) Dengan hapusnya Hak

Tanggungan, sertipikat Hak

Tanggungan yang bersangkutan ditarik dan bersama-sama buku tanah Hak Tanggungan dinyatakan tidak berlaku lagi oleh Kantor Pertanahan.

(3) Apabila sertipikat sebagaimana dimaksud pada ayat (2) karena sesuatu sebab tidak dikembalikan kepada Kantor Pertanahan, hal tersebut dicatat pada buku tanah Hak Tanggungan.

(4) Permohonan pencoretan sebagaimana dimaksud pada ayat (1) diajukan oleh pihak yang berkepentingan dengan melampirkan sertipikat Hak Tanggungan yang telah diberi catatan oleh kreditor bahwa Hak Tang-gungan hapus karena piutang yang dijamin pelunasan-nya dengan Hak Tanggungan itu sudah lunas, atau pernyataan tertulis dari kreditor bahwa Hak Tanggungan telah hapus karena piutang yang dijamin pelunasannya dengan Hak Tanggungan itu telah lunas atau karena kreditor melepaskan Hak Tanggungan yang bersangkutan.

(5) Apabila kreditor tidak bersedia memberikan pernya-taan sebagaimana dimaksud pada ayat (4), pihak yang berkepentingan dapat mengajukan permohonan perintah pencoretan tersebut kepada Ketua Pengadilan Negeri yang daerah hukumnya meliputi tempat Hak Tanggungan yang bersangkutan didaftar.

(6) Apabila permohonan perintah pencoretan timbul dari sengketa yang sedang diperiksa oleh Pengadilan Negeri lain, permohonan tersebut harus diajukan kepada Ketua Pengadilan Negeri yang memeriksa perkara yang bersangkutan. 
(7) Permohonan pencoretann catatan Hak Tanggungan berdasarkan perintah Pengadilan Negeri sebagaimana dimaksud pada ayat (5) dan ayat (6) diajukan kepada Kepala Kantor Pertanahann dengan melampirkan salinan penetapan atau putusan Pengadilan Negeri yang bersangkutan.

(8) Kantor Pertanahan melakukan pencoretan catatan Hak Tanggungan Hak Tanggungan menurut tata cara yang ditentukan dalam peraturan perundangundangan yang berlaku dalam waktu 7 (tujuh) hari kerja terhitung sejak diterimanya permohonan sebagaimana dimaksud pada ayat (4) dan ayat (7).

(9) Apabila pelunasan utang dilakukan dengan cara angsuran sebagaimana dimaksud dalam Pasal 2 ayat (2), hapusnya Hak Tanggungan pada bagian obyek Hak Tanggungan yang bersangkutan dicatat pada buku tanah dan sertipikat Hak Tanggungan serta pada buku tanah dan sertipikat hak atas tanah yang telah bebas dari Hak Tanggungan yang semula membebaninya.

(10) Dalam keadaan tertentu sebagaimana yang ditentukan oleh Menteri Kepala Kantor Pertanahan dapat mendaftar pemindahan hak atas bidang tanah hak milik, yang dilakukan di antara perorangan warga negara Indonesia yang dibuktikan dengan akta yang tidak dibuat oleh PPAT, tetapi yang menurut Kepala Kantor Pertanahan tersebut kadar kebenarannya dianggap cukup untuk mendaftar pemindahan hak yang bersangkutan.

Setelah dilakukan pencoretan, UUHT memerintahkan kepada para pihak yang berkepentingan untuk melakukan pendaftaran hapusnya Hak Tanggungan sebagaimana diatur di dalam Pasal 54 menentukan:

(1) Pendaftaran hapusnya hak tanggungan dilakukan sesuai ketentuan dalam Undangundang Nomor 4 Tahun 1996 tentang Hak Tanggungan Atas Tanah Beserta Bendabenda Yang Berkaitan dengan Tanah.

(2) Dalam hal hak yang dibebani hak tanggungan telah dilelang dalam rangka pelunasan utang, maka surat pernyataan dari kreditor bahwa pihaknya melepaskan hak tanggungan atas hak yang dilelang tersebut untuk jumlah yang melebihi hasil lelang beserta kutipan risalah lelang dapat dijadikan dasar untuk pendaftaran hapusnya hak tanggungan yang bersangkutan.

Pendaftaran pencoretan/hapusnya (roya) Hak Tanggungan ini juga dimaksudkan agar memberikan kepastian hukum bahwa sertifikat hak atas tanah tersebut tidak lagi dibebani dengan Hak Tanggungan. Dengan demikian maka pemilik tanah dapat melakukan perbuatan hukum apa saja di atas tanah tersebut, baik perbuatan hukum jual beli, tukar menukar, sewa menyewa, dan lainnya, termasuk perbuatan hukum menjadikan jaminan hutang lagi pada orang-orang atau badan hukum.

3. Peraturan Pemerintah Nomor 10 Tahun 1961 junto Peraturan Pemerintah Nomor 24 Tahun 1997 tentang Pendaftaran Tanah.

Peraturan Pemerintah Nomor 10 Tahun 1961 Pasal 19 menentukan: Setiap pejanjian yang bermaksud memindahkan hak atas tanah, memberikan sesuatu hak baru atas tanah, menggadaikan tanah atau meminjam uang dengan hak atas tanah sebagai tanggungan, harus dibuktikan dengan suatu akte yang dibuat oleh dan dihadapan penjabat yang ditunjuk oleh Menteri Agraria (selanjutnya dalam Peraturan Pemerintah ini disebut: penjabat). Akte tersebut bentuknya ditetapkan oleh Menteri Agraria. 
Sedangkan Peraturan Pemerintah Nomor 24 Tahun 1997 tentang Pendaftaran Tanah di dalam Pasal 37 ayat (1) menentukan: Peralihan hak atas tanah dan hak milik atas satuan rumah susun melalui jual beli, tukar menukar, hibah, pemasukan dalam perusahaan dan perbuatan hukum pemindahan hak lainnya, kecuali pemindahan hak melalui lelang, hanya dapat didaftarkan, jika dibuktikan dengan akta yang dibuat oleh PPAT yang berwenang menurut ketentuan peraturan perundang-undangan yang berlaku.

4. Peraturan Menteri Negara Agraria/Kepala Badan Pertanahan Nasional Nomor 3 Tahun 1997 Tentang Ketentuan Pelaksanaan Peraturan Pemerintah Nomor 24 Tahun 1997 Tentang Pendaftaran Tanah. Di Pasal 114 s/d 124 peraturan ini mengatur secara khusus tentang Pendaftaran dan Hapusnya (roya) Hak Tanggungan. Pendaftaran hapusnya (roya) Hak Tanggungan

Pasal 124 menentukan:

(1) Pendaftaran hapusnya Hak Tanggungan atas sebagian obyek Hak Tanggungan dapat dilakukan berdasarkan pelunasan sebagian utang yang dijamin, dengan ketentuan bahwa:

1) obyek Hak Tanggungan terdiri dari beberapa hak, dan

2) kemungkinan hapusnya sebagian Hak Tanggungan karena pelunasan sebagian utang tersebut diperjanjikan di dalam Akta Pemberian Hak Tanggungan.

(1) Pendaftaran hapusnya Hak Tanggungan atas sebagian obyek Hak Tanggungan juga dapat dilakukan walaupun tidak memenuhi ketentuan ayat (1) berdasarkan pelepasan Hak Tanggungan atas sebagian obyek Hak Tanggungan oleh pemegang Hak Tanggungan yang dituangkan dalam akta otentik atau surat pernyataan di bawah tangan dengan mencantumkan secara jelas bagian dari obyek Hak Tanggungan yang dibebaskan dari beban Hak Tanggungan itu.

(2) Pendaftaran hapusnya Hak Tanggungan atas sebagian obyek Hak Tanggungan yang merupakan suatu hak yang sudah terdaftar tersendiri dilakukan sesuai ketentuan sebagaimana dimaksud dalam Pasal 123.

(3) Pendaftaran hapusnya Hak Tanggungan atas sebagian dari obyek Hak Tanggungan yang tidak merupakan suatu hak atas tanah yang terdaftar tersendiri karena merupakan bagian dari hak atas tanah yang lebih besar dilakukan setelah dilakukan pemecahan atau pemisahan bidang tanah sebagaimana dimaksud dalam Pasal 133 dan 134.

Ketentuan-ketentuan tersebut memberikan pedoman kepada pemerintah, dalam hal ini Kepala Kantor Pendaftaran Tanah dan para pihak yang berkepentingan dengan pemberian dan peghapusan Hak Tanggungan sebagai jaminan Hutang, baik pada lembaga perbankan maupun pada perseorangan guna kepastian hukum dan kemudahan dalam melakukan eksekusi jika terjadi kreditur wanprestasi.

\section{B. Efektivitas Pelaksanaan Roya (Pencoretan) Hak Tanggungan Atas Tanah Setelah Berakhirnya Perjanjian Kredit Di Kantor ATR/BPN Kota Mataram}

Setiap berakhirnya kredit maka demi hukum berakhir pula Hak Tanggungan tersebut. Namun ada kewajiban baru yang akan dilakukan oleh pihak debitur dan kreditur, yaitu melakukan pendaftaran Roya (pencoretan). Jadi roya (pencoretan) Hak Tanggungan setelah berakhirnya perjanjian kredit merupakan keharusan yang dilakukan oleh para pihak yang berkepentingan, dalam hal ini pihak 
debitur dan kreditur. Pencoretan ini dimaksudkan agar obyek Hak Tanggungan tersebut tidak lagi terikat dengan jaminan kredit.

Berdasarkan data dan hasil wawancara peneliti dengan informan (Bank-bank, Kepala kantor Pendaftaran Tanah/BPN Kota Mataram dan beberapa Pejabat Pembuat Akta Tanah) dan responden (beberapa debitur/pemeberi Hak Tanggungan) yang dianalisis oleh tim peneliti menunjukan bahwa selama ini pendaftaran pembebanan dengan Hak Tanggungan terhadap kredit yang baru maupun pendaftaran penghapusan (roya) Hak Tanggungan terhadap kredit yang telah dilunasi oleh debitur atau telah berakhir masa kreditnya telah berjalan dengan baik dan lancar.

Pihak Bank selaku kreditur sangat menyadari akan pentingnya pendaftaran Hak Tanggungan pada Kantor Pendaftaran karena berkaitan dengan kekuatan hukum dan eksekusi Hak Tanggungan Tersebut jika suatu saat debitur wanpretasi, sebab jika Hak Tanggungan tersebut tidak didaftarkan maka akibatnya perjanjian Hak Tanggungan itu tidak mempunyai kekuatan hukum dan akan mengalami kesulitan untuk melakukan eksekusi jika terjadi wanprestasi debitur. Demikian juga jika transaksi kreditnya sudah dilunasi oleh debitur, maka pihak bank merasa berkewajiban untuk melakukan pendaftaran penghapusan (roya) Hak Tanggungan tersebut pada Kantor Pendaftaran Tanah Kantor Pertanahan Kabupatin/Walikota.

Demikian pula hasil wawancara kami dengan responden, yaitu debitur yang telah melunasi kreditnya dan telah melakukan roya' (pencoretan) Hak Tanggungannya. Mereka sadar bahwa pendaftaran dan pencoretan Hak Tanggungan itu adalah sangat penting, karena dengan pendaftaran itu menentukan status hukum Hak Tanggungan atas Tanah. Apabila Kreditur belum melakukan pendaftaran roya' (pencoretan) Hak Tanggungan atas tanahnya, maka para debitur yang telah melunasi segala kewajiban utang piutangnya melakukan pendaftaran.

Keterangan dari para kreditur dan debitur di atas didukung pula oleh penjelasan yang telah disampaikan oleh pihak Kepala Kantor Pendaftaran Tanah pada Kantor ATR/Badan Pertanahan Kota Mataram yang menyatakan bahwa pelaksanaan pendaftaran Hak Tanggungan dan pendaftaran penghapusan (roya') Hak Tanggungan berjalan dengan baik. Ini menunjukan bahwa para pihak yang melakukan hubungan hukum berupa hutang piutang dengan jaminan Hak Atas Tanah sangat sadar akan pentingnya pendaftaran Hak Tanggungan atau pendaftaran pencoretan Hak Tanggungan. Ini ditunjukan oleh adanya pelaksanaan pendaftaran Hak Tanggungan dan pendaftaran penghapusan Hak Tanggungan di Kantor Pendaftaran Tanah Kota Mataram dalam 3(tiga) Tahun terakhir (2015-2017) sebagaimana tertera pada tabel-tabel berikut ini.

\section{KANTOR PERTANAHAN KOTA MATARAM 2015}

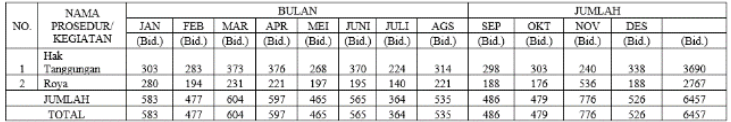

Sumber Data: Kantor Pertanahan Kota Mataram, 2017.

\section{KANTOR PERTANAHAN KOTA} MATARAM 2016

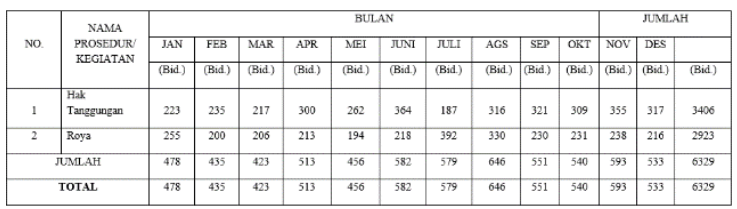

Sumber Data: Kantor Pertanahan Kota Mataram 2017

KANTOR PERTANAHAN KOTA MATARAM 2017

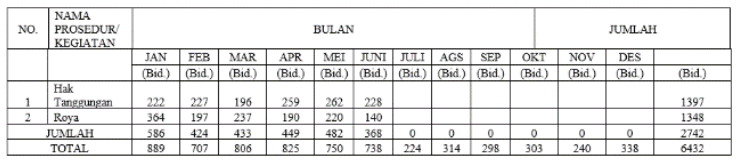

Sumber Data: Kantor Pertanahan Kota 
Mataram 2017

Berdasarkan data yang tertera dalam ke tiga table tersebut di atas maka dapat dijelaskan sebagai berikut:

1 .

endaftaran peralihan hak atas tanah tersebut dilakukan atas dasar perintah Peraturan Pemerintah Nomor 24 Tahun 1997 tentang Pendaftaran Tanah. Di dalam ketentuan Pasal 11 menentukan: Pelaksanaan pendaftaran tanah meliputi kegiatan pendaftaran tanah untuk pertama kali dan pemeliharaan data pendaftaran tanah. Selanjutnya dalam Pasal 12 ayat (2) menentukan: Kegiatan pemelihaan data pendaftaran tanah meliputi : a. pendaftaran peralihan dan pembebanan hak; $b$. pendaftaran perubahan data pendaftaran tanah lainnya. Setiap pendaftaran peralihan hak harus dbuktikan dengan akta sebagaimana ditetukan di dalam Pasal 37 (1) menentukan bahwa Peralihan hak atas tanah dan hak milik atas satuan rumah susun melalui jual beli, tukar menukar, hibah, pemasukan dalam perusahaan dan perbuatan hukum pemindahan hak lainnya, kecuali pemindahan hak melalui lelang, hanya dapat didaftarkan, jika dibuktikan dengan akta yang dibuat oleh PPAT yang berwenang menurut ketentuan peraturan perundang-undangan yang berlaku. Selanjutnya di Pasal 37 ayat (2) ditentukaan bahwa dalam keadaan tertentu sebagaimana yang ditentukan oleh Menteri, Kepala Kantor Pertanahan dapat mendaf-tar pemindahan hak atas bidang tanah hak milik, yang dilakukan di antara perorangan warga negara Indonesia yang dibuktikan dengan akta yang tidak dibuat oleh PPAT, tetapi yang menurut Kepala Kantor Pertanahan tersebut kadar kebenarannya dianggap cukup untuk mendaftar pemindahan hak yang bersangkutan.

2.

etiap perbuatan hukum menjadikan hak atas tanah sebagai Hak Tanggungan wajib didaftarkan. Sehubungan dengan hal tersebut, maka setiap pelaksanaan pemberian Hak Tanggungan oleh debitur kepada kreditur di wilayah hukum Kantor Agraria dan Tata Ruang/Kantor BPN Kota Mataram selama 3(tiga) tahun terakhir berjalan dengan baik sesuai dengan ketentuan hukum yang berlaku; Pemberi Hak Tanggungan dan penerima Hak Tanggungan, sangat menyadari bahwa perbuatan hukum peralihan hak atas tanah wajib dilakukan pendaftaran guna memberikan jaminan kepastian hukum dan hak, serta mempermudah pihak kreditur untuk melakukan eksekusi hak tanggungan tersebut jika debitur wanprestasi.

3.

adar akan pentingnya pendaftaran hak atas tanah dan pendaftaran segala perbuatan hukum yang berkaitan dengan tanah, maka para pihak yang terkait dengan perbuatan hukum tersebut selalu berusaha untuk melakukan pendaftaran peralihan hak atas tanah, termasuk salah satu perbuatan hukum peralihan hak berupa menjadikan hak atas tanah sebagai jaminan atau Hak Tanggungan.

\section{PENUTUP}

A.

\section{Simpulan}

a. Pengaturan hukum tentang proses pelaksanaan roya (pencoretan) Hak Tanggungan Atas Tanah setelah berakhirnya perjanjian kredit adalah diatur di dalam Undang-Undang Hak Tanggungan Pasal 22 dan Pasal 54. Pasal 22, Sebagai pelaksanaan dari ketentuan Undang-Undang diatur pula dalam Peraturan Pemerintah Nomor 24 Tahun 1997 tentang Pendaftaran Tanah. Selanjutnya Menteri Negara Agraria/Kepala Badan Pertanahan Nasional mengeluarkan Peraturan Menteri Negara Agraria/Kepala Badan Pertanahan Nasional Nomor 3 Tahun 1997 Tentang Ketentuan Pelaksanaan 
Peraturan Pemerintah Nomor 24 Tahun 1997 Tentang Pendaftaran Tanah.

b. Pelaksanaan pendaftaran roya (pencoretan) Hak Tanggungan Atas Tanah setelah berakhirnya perjanjian kredit di Kantor ATR/BPN Kota Mataram berjalan dengan efektif sesuai dengan perintah UUHT dan peraturan perundangan-undangan yang berlaku. Setiap pemberian Hak Tanggungan dan penghapusan Hak Tanggungan (roya) selalu dilakukan pendaaftaran. Efektifnya ini disebabkan tingkat kesadaran debitur dan kreditur pemberi dan pemegang Hak Tanggungan sduah cukup Tinggi.

\section{B. Saran-saran}

Badan Pertanahan maupun Pejabat Pembuat Akta Tanah hendaknya selalu memberikan pemahaman kepada pemberi Hak Tanggungan maupun penerima Hak Tanggungan untuk selalu mendaftarkan Hak Tanggungan dan Penghapusan Hak Tanggungan guna memberikan jaminan kepastian hukum para pihak.

\section{DAFTAR PUSTAKA}

Arba, H.M., Hukum Agraria Indonesia, Sinar Grafika, Jakarta, 2015, hal. 2008.

Adrian Sutedi, Hukum Hak Tanggungan, Sinar Grafika, Jakarta, 2012.

Boedi Harsono, Hukum Agraria Indonesia, Sejarah Pembentukan UUPA, Isi dan Pelaksanaannya, Jakarta, Djambatan, 1999.

Mukti Fajar ND dan Yulianto Achmad, Dualisme Penelitian Hukum, Normatif dan Empiris, Yogyakarta, Pustaka Pelajar, 2010.

ST. Remy Sjahdeini, Hak Tanggungan, Asas-asas, Ketentuan-Ketentuan Pokok dan Masalah Yang Dihadapi
Oleh Perbankan (Suatu Kajian

Mengenai Undang-Undang Hak

Tanggungan, Bandung, Alumni, 1999.

Soerjono Soekanto, Pengantar Penelitian Hukum, Universitas Indonesia, Pres. Jakarta. 1984.

S. Nasution, Penelitian KualitatifNaturalitik, Bandung, Tarsito, 1986.

\section{Peraturan Perundang-Undangan:}

Undang-Undang Dasar Tahun 1945 yang telah diamandemen

Undang-Undang Nomor 5 Tahun 1960 tentang Ketentuan Dasar Pokok-pokok Agraria.

Undang-Undang Nomor 4 Tahun 1996 tentang Hak Tanggungan Atas Tanah dan Benda-benda yang Ada Di Atasnya.

Peraturan pemerintah Nomor 10 Tahun 1961 tentang Pendaftaran Tanah.

Peraturan Pemerintah Nomor 24 Tahun 1997 tentang Pendaftaran Tanah 